\title{
Effect of Sweet Potato Starch Addition on the Proximate Composition, Energy Content and Sensory Properties of Stirred Yoghurts
}

\author{
Okoye, J. I. ${ }^{1}$, Obi, C. D. ${ }^{2}$ \\ ${ }^{1}$ Department of Food Science and Technology, Enugu State University of Science and Technology, P.M.B 01660, Enugu, Nigeria. \\ ${ }^{2}$ Department of Food Technology, Federal Polytechnic, Oko, Nigeria
}

\begin{abstract}
The proximate composition, energy content and sensory properties of stirred yoghurts stabilized with sweet potato starch were studied. The stirred yoghurt was prepared from whole milk powder and other basic ingredients. The product obtained after fermentation was divided into five equal portions and then stabilized by the addition of sweet potato starch at the levels of 10, 15, 20, 25 and 30\% to produce different samples of yoghurt. The stirred yoghurts produced were analysed for proximate composition, energy content and sensory qualities using standard methods. The results of the proximate composition and energy content of the samples showed that the samples contained, 77.58 - $82.62 \%$ moisture, 5.48 - 6.96\% crude protein, 4.08 - $6.54 \%$ fat, $0.76-1.14 \%$ ash, $0.56-0.78 \%$ crude fibre, $3.12-11.32 \%$ carbohydrate and $93.64-105.62 \mathrm{KJ} / 100 \mathrm{~g}$ energy, respectively. The sensory evaluation showed that the plain or unstabilized yoghurt used as control was most acceptable by the judges and also differed significantly ( $p \leq 0.05)$ from the other samples in colour and palatability. However, the sample stabilized with $30 \%$ sweet potato starch was scored highest in flavour and texture.
\end{abstract}

Keywords: Yoghurt, proximate composition, energy content, sensory quality, sweet potato starch

\section{Introduction}

Yoghurt is a dairy product produced by bacterial fermentation of milk. Any sort of milk may be used to make yoghurt, but modern production is dominated by cow's milk. Yoghurt is one of the most commonly available cultured dairy products in the developed countries of the world where its popularity is derived from its flavour and versatility (Adams and Moss, 1999). Yoghurt is a fermented milk product in which the milk sugar (lactose) is converted into lactic acid by the addition of a characteristic culture of lactic acid - producing bacteria, Lactobacillus bulgaricus and Streptococcus thermophilus. The aroma, body and flavour of yoghurt and other cultured diary products can vary depending on the type of culture and milk, amount of milk fat and non-fat milk solids, fermentation process and temperature used (Salvador and Fiszman, 2004). The use of food starches extracted from a variety of inexpensive and available dietary staples such as cereals, roots and tubers as stabilizers in the production of yoghurt has not gained momentum in most developing countries of the tropics in recent times. This is because the consistency and firmness of yoghurt are drastically improved by the addition of stabilizers or hydrocolloids such as pectin, gelatin, guar-gum and locust bean gum (Hansen, 1993). Sweet potato starch is one of the cheapest sources of carbohydrate yet to be exploited for yoghurt production in Nigeria. The successful utilization of sweet potato starch as a stabilizer in the preparation of yoghurt can lead to economic break through and reduce the problem of protein - energy malnutrition prevalent among school children and adolescents in several sub-saharan African countries as a result of hunger and poverty. The purpose of this study is to determine the proximate composition, energy content and sensory qualities of stirred yoghurts stabilized with different proportions of sweet potato starch.

\section{Materials and Methods}

The whole milk powder, sugar (sucrose), starter culture and sweet potato starch used for this study were purchased from Owerri Main Market, Imo State, Nigeria.

\section{Preparation of Yoghurts}

The stirred yoghurts were prepared according to the method of Kumar and Mishra (2004). The recipe used for the preparation of the yoghurt contained $100 \%$ whole milk powder, $60 \%$ water, $4 \%$ starter culture and $6 \%$ sugar (sucrose). During preparation, the whole milk powder was initially prepared into milk solution by dissolving 500 grams of the milk powder with two litres of potable water in a plastic bowl. The milk solution obtained was immediately pasteurized in an electrically heated pot at $65^{\circ} \mathrm{C}$ for $30 \mathrm{~min}$. During pasteurization, transparent precipitates of scum-curd formed as a result of heat were gradually skimmed off. After that, the pasteurized milk solution was manually stirred with a sterilized stainless steel stirrer and then transferred into another plastic bowl. The stirred milk solution was allowed to cool to $43^{\circ} \mathrm{C}$ and on cooling, sugar (sucrose) was added and the cooled milk solution was inoculated with the mixed culture of Lactobacillus bulgaricus and Streptococcus thermophilus (yoghurt starters). The mixture was allowed to ferment in a well-covered plastic bowl at room temperature $\left(30 \pm 2^{0} \mathrm{C}\right)$ for $12 \mathrm{~h}$. After fermentation, the yoghurt produced was cooled in an ice bath placed in a cabinet at $4^{0} \mathrm{C}$ and stirred. The cooled and stirred yoghurt was divided into five equal portions and then stabilized by the addition of sweet potato starch at the levels of 10, 15, 20, 25 and $30 \%$, respectively. After that, the various samples of stabilized yoghurt obtained were gradually covered and allowed to stand for another $2 \mathrm{~h}$, after which, they were stirred thoroughly for $5 \mathrm{~min}$. The stirred yoghurts produced were packaged individually in sterilized air tight plastic can and kept in refrigerated conditions until used for analysis. The 


\section{International Journal of Science and Research (IJSR) \\ ISSN (Online): 2319-7064 \\ Index Copernicus Value (2013): 6.14 | Impact Factor (2015): 6.391}

plain or unstabilized yoghurt was similarly prepared and used as control.

\section{Chemical Analysis}

The moisture, crude protein, fat, ash and crude fibre contents of the samples were determined in triplicate according to the method of AOAC (2006). Carbohydrate was determined by difference (Onwuka, 2005). The energy content of the samples was determined using the Parr adiabatic oxygen Bomb calorimeter according to AOAC (2006).

\section{Sensory Evaluation}

The yoghurts were evaluated for consumer acceptance and preference by a panel of twenty (20) semi-trained judges drawn from the University Community for attributes of colour, flavour, texture, palatability and overall acceptability. Coded samples of the same size were served in a white ceramic plate of the same size with a white plastic spoon to the judges at ambient temperature $\left(30 \pm 2^{\circ} \mathrm{C}\right)$ with cold water for rinsing. The judges were asked to indicate the preference and acceptance for the samples using a nine point Hedonic scale with 1 and 9 representing dislike extremely and like extremely, respectively (Iwe, 2002).

\section{Statistical Analysis}

The data obtained were analysed using Analysis of variance (ANOVA) to detect significant differences at $p \leq 0.05$ ). The Turkey's least significant difference test (LSD) was used in separating significant means (Okaka, 2010).

\section{Results and Discussion}

The proximate composition of yoghurts are shown in Table 1. The moisture content of the samples showed significant $(\mathrm{p} \leq 0.05)$ difference between the samples. The result, however, is in close agreement with the report of Everett and McLeod (2005). Moisture content of food is of great importance to every food processor as a number of biochemical reactions and physiological changes in food depend very much on the moisture content (Kumar and Mishra, 2004). The crude protein content of the yoghurts ranged from 5.54 to $6.96 \%$. The differences could be due to variation in the level of sweet potato starch added as a stabilizer during preparation. The values obtained in this study were similar to those $(5.56-6.94 \%)$ reported by Bhullar et al. (2002) for stirred skim-milk yoghurts. Protein functionality promotes growth, tissue repair and maintenance. Dietary proteins are needed for the synthesis of new cells, enzymes, hormones and other substances required for healthy functioning and development of the body (Okaka et al., 2006). The fat content of the samples was generally higher than those (2.36-394\%) previously reported for stirred whole milk yoghurts. This is an indication that the products are of high fat content. Fat is important in diets because it promotes the absorption of fatsoluble vitamins (Ikenebomeh and Omogbai, 2000) and is in itself a high energy-yielding nutrient. The ash content of the yoghurts ranged from 0.76 to $1.14 \%$. The variation in ash content of the samples could be attributed to differences in the amount of sweet potato starch added during preparation. The observation is in agreement with the report of Hassan et al. (2003). The low ash content recorded by the samples is an indication that they are not good sources of minerals. The crude fibre content of the samples was significantly $(\mathrm{p} \leq 0.05)$ increased with increased level of sweet potato starch in the products. The result, however, indicates that sweet potatoes are good sources of crude fibre. Fibre plays a significant role in the maintenance of intestinal distention for a normal peristaltic movement of the gastrointestinal tract in the body (Everett and McLeod, 2005). The carbohydrate content of the samples which ranged from 3.12 to $11.32 \%$ was significantly $(\mathrm{p} \leq 0.05)$ increased with increased level of sweet potato starch in the products. The values obtained in this study were higher than those $(3.08-8.68 \%)$ reported by Martin et al. (1999) for plain low fat stirred yoghurts. The energy content of the yoghurts ranged from 93.64 to $105.62 \mathrm{KJ} / 100 \mathrm{~g}$. The variation in energy content of the samples could be due to differences in their protein, fat and carbohydrate contents (Ikenebomeh and Omogbai, 2000). Generally, the increase in the nutrient density recorded by the yoghurts as a result of the incorporation of sweet potato starch is an indication that the products can meet the protein - energy needs of consumers especially in regions where protein - energy malnutrition is prevalent among children and adolescents. Table 2 shows the sensory properties of yoghurts. The scores of the sensory attributes were generally high in all the samples of yoghurt evaluated. However, the plain or unstabilized yoghurt used as control was most acceptable by the judges and also differed significantly $(p \leq 0.05)$ from the other samples in colour and palatability. The differences could be attributed to the unique quality of animal milk in the preparation of different types of yoghurt (Gallardo - Escamilla et al., 2007). In addition, the result also indicated that the sample stabilized with $30 \%$ sweet potato starch had better flavour and texture than the control. The improvement in flavour and texture of the sample could be due to the ability of sweet potato starch to bind water and form stable network of protein in the product during preparation (Martin et al., 1999). However, the use of sweet potato starch as a stabilizer in yoghurt production at a level up to $30 \%$ produced good and acceptable results.

\section{Conclusion}

The study showed that the nutritional and sensory qualities of stirred yoghurts can be greatly improved by the addition of sweet potato starch as a stabilizer. The observation from the study also indicated that the sample stabilized with $30 \%$ sweet potato starch had higher fibre, carbohydrate and energy contents and better flavour and texture than the other samples. In essence, the incorporation of sweet potato starch as a stabilizer in the production of stirred yoghurts should be encouraged in order to enhance their nutritional and sensory qualities. 


\section{International Journal of Science and Research (IJSR) \\ ISSN (Online): 2319-7064}

Index Copernicus Value (2013): 6.14 | Impact Factor (2015): 6.391

Table 1: Proximate Composition and Energy Content of Yoghurts

\begin{tabular}{|c|c|c|c|c|c|c|c|}
\hline Samples & Moisture (\%) & Crude Protein (\%) & Fat (\%) & Ash (\%) & Crude Fibre (\%) & Carbohydrate (\%) & Energy KJ/100g \\
\hline A & $82.62^{\mathrm{a}} \pm 2.03$ & $6.96^{\mathrm{a}} \pm 0.03$ & $6.54^{\mathrm{a}} \pm 0.02$ & $0.76^{\mathrm{d}} \pm 0.13$ & $0.56^{\mathrm{d}} \pm 0.12$ & $3.12^{\mathrm{e}} \pm 0.06$ & $99.18^{\mathrm{e}} \pm 2.18$ \\
\hline B & $82.26^{\mathrm{b}} \pm 2.14$ & $6.02^{\mathrm{b}} \pm 0.05$ & $5.16^{\mathrm{b}} \pm 0.03$ & $0.78^{\mathrm{d}} \pm 0.12$ & $0.63^{\mathrm{c}} \pm 0.13$ & $5.79^{\mathrm{d}} \pm 0.05$ & $93.64^{\mathrm{f}} \pm 2.24$ \\
\hline C & $79.92^{\mathrm{c}} \pm 1.9$ & $5.54^{\mathrm{c}^{\mathrm{a}}} \pm 0.04$ & $4.42^{\mathrm{c}} \pm 0.07$ & $0.76^{\mathrm{d}} \pm 0.12$ & $0.68^{\mathrm{b}} \pm 0.14$ & $9.36^{\mathrm{c}} \pm 0.08$ & $99.38^{\mathrm{d}} \pm 2.32$ \\
\hline D & $78.90^{\mathrm{d}} \pm 1.72$ & $5.54^{\mathrm{c}} \pm 0.04$ & $4.29^{\mathrm{d}} \pm 0.08$ & $0.86^{\mathrm{c}} \pm 0.10$ & $0.68^{\mathrm{b}} \pm 0.14$ & $10.22^{\mathrm{b}} \pm 0.04$ & $102.41^{\mathrm{c}} \pm 2.42$ \\
\hline E & $78.96^{\mathrm{e}} \pm 1.82$ & $5.56^{\mathrm{c}} \pm 0.05$ & $4.26^{\mathrm{d}} \pm 0.08$ & $1.06^{\mathrm{b}} \pm 0.09$ & $0.72^{\mathrm{b}} \pm 0.13$ & $10.24^{\mathrm{b}} \pm 0.04$ & $102.65^{\mathrm{b}} \pm 2.42$ \\
\hline F & $77.58^{\mathrm{f}} \pm 1.80$ & $5.48^{\mathrm{d}} \pm 0.06$ & $4.08^{\mathrm{e}} \pm 0.06$ & $1.14^{\mathrm{a}} \pm 0.08$ & $0.78^{\mathrm{a}} \pm 0.12$ & $11.32^{\mathrm{a}} \pm 0.07$ & $105.62^{\mathrm{a}} \pm 2.44$ \\
\hline
\end{tabular}

A - Plain or unstabilized yoghurt, B - Yoghurt stabilized with $10 \%$ sweet potato starch, C - Yoghurt stabilized with $15 \%$ sweet potato starch, D - Yoghurt stabilized with $20 \%$ sweet potato starch, E - Yoghurt stabilized with 25\% sweet potato starch, F - Yoghurt stabilized with $30 \%$ sweet potato starch. Values are means \pm Standard deviation of triplicate determinations. Means in the same column with different superscripts are significantly different $(\mathrm{p} \leq 0.05)$.

Table 2: Sensory Properties of Yoghurts

\begin{tabular}{|c|c|c|c|c|c|}
\hline Samples & Colour & Flavour & Texture & Palatability & Overall Acceptability \\
\hline A & $8.6^{\mathrm{a}} \pm 0.03$ & $6.2^{\mathrm{d}} \pm 0.04$ & $6.0^{\mathrm{d}} \pm 0.04$ & $8.0^{\mathrm{a}} \pm 0.02$ & $8.6^{\mathrm{a}} \pm 0.03$ \\
\hline B & $6.4^{\mathrm{e}} \pm 0.05$ & $6.0^{\mathrm{d}} \pm 0.04$ & $6.2^{\mathrm{d}} \pm 0.04$ & $7.4^{\mathrm{b}} \pm 0.06$ & $7.6^{\mathrm{a}} \pm 0.06$ \\
\hline C & $6.8^{\mathrm{e}} \pm 0.05$ & $6.6^{\mathrm{c}} \pm 0.05$ & $6.8^{\mathrm{c}} \pm 0.05$ & $7.0^{\mathrm{c}} \pm 0.06$ & $7.4^{\mathrm{b}} \pm 0.06$ \\
\hline D & $7.6^{\mathrm{c}} \pm 0.06$ & $7.4^{\mathrm{b}} \pm 0.06$ & $7.0^{\mathrm{c}} \pm 0.06$ & $6.4^{\mathrm{d}} \pm 0.05$ & $6.8^{\mathrm{c}} \pm 0.05$ \\
\hline E & $7.0^{\mathrm{d}} \pm 0.06$ & $7.6^{\mathrm{b}} \pm 0.06$ & $7.6^{\mathrm{b}} \pm 0.06$ & $7.2^{\mathrm{b}} \pm 0.06$ & $6.0^{\mathrm{d}} \pm 0.04$ \\
\hline F & $8.0^{\mathrm{b}} \pm 0.02$ & $8.4^{\mathrm{a}} \pm 0.03$ & $8.2^{\mathrm{a}} \pm 0.02$ & $6.0^{\mathrm{d}} \pm 0.04$ & $6.2^{\mathrm{d}} \pm 0.04$ \\
\hline
\end{tabular}

A - Plain or unstabilized yoghurt, B - Yoghurt stabilized with $10 \%$ sweet potato starch, C - Yoghurt stabilized with $15 \%$ sweet potato starch, D - Yoghurt stabilized with $20 \%$ sweet potato starch, E - Yoghurt stabilized with 25\% sweet potato starch, F - Yoghurt stabilized with $30 \%$ sweet potato starch.

Values are means \pm Standard deviation of 20 semi-trained judges. Means in the same column with different superscripts are significantly different $(\mathrm{p} \leq 0.05)$.

\section{References}

[1] Adams, M.R. and Moss, M.O. (1999). Food Microbiology. Athenaeum Publishing Company Ltd, New Delhi, India. Pp. 398 - 402.

[2] AOAC (2006). Official Methods of Analysis. Association of Official Analytical Chemists. $18^{\text {th }}$ edn. Washington, D.C. pp. $186-192$.

[3] Bhullar, Y.S., Uddin, M.A. and Sha, N.P. (2002). Effects of ingredients supplementation on the textural characteristics and microstructure of yoghurt. Michwissenchaft; 57:328-322.

[4] Enwere, N.J. (1998). Foods of Plant Origin. Afro-Obis publications Ltd, Nsukka, Nigeria. Pp. $106-109$.

[5] Everett, D.W. and McLeod, R.E. (2005). Interactions of polysaccharide stabilizers with casein aggregates in stirred skim-milk yoghurt. International Journal of Dairy Science; 15:1175 - 1183.

[6] GalLardo-Escamilla, F.J, Kelly, A.L. and Delahunt, C. M. (2007). Mouthfeel and flavour of fermented whey with added hydrocolloids. International Journal of Dairy Science; 17: 308 - 315.

[7] Hansen, W.J. (1993). Yoghurt Production. In: Dairy Technology and Engineering. $3^{\text {rd }}$ edn. Avi Publishing Company Inc. Westport, Connection. Pp. 364 - 372.

[8] Hassan, A.N., Ipsen, R., Janzen, T. and Ovist, K.B. (2003). Microstructure and rheology of yoghurt made with cultures differing only in their ability to produce exopolysaccharides. Journal of Dairy Science; 86: $1632-1638$.

[9] Ikenebomeh, M.J. and Omogbai, B.A. (2000). Chemical analysis and sensory investigation of soymilk yoghurts. Nigerian Journal of Microbiology; 14(2): $85-93$.

[10] Iwe, M.O. (2002). Handbook of Sensory Methods and Analysis. Rejoint Communication Services Ltd, Enugu, Nigeria. Pp. $72-78$.

[11] Kumar, P. and Mishra, H.N. (2004). Effect of stabilizer addition on physicochemical, sensory and textural properties of soy fortified set yoghurt. Journal of Food Chemistry; 87:501-507.

[12] Martin, N.C., Skokanowa, J., Latrille, E., Beal, C. and Corrieu, G. (1999). Influence of fermentation and storage conditions on sensory properties of plain low fat stirred yoghurts. Journal of studies; 14: $139-156$.

[13] Okaka, J.C., Akobundu, E.N.T and Okaka, A.N.C. (2006). Food and Human Nutrition: An Integrated Approach $3^{\text {rd }}$ end. Ocjanco Academic Publishers, Enugu, Nigeria. Pp. 126 - 140.

[14] Okaka, J.C. (2010). Teach Yourself Sensory Evaluation and Experimentation. Ocjanco Academic Publishers, Enugu, Nigeria. Pp. 76-78.

[15] Okoye, J.I., Nkwocha, A.C. and Ogbonnaya, A.E. (2008). Production, proximate composition and consumer acceptability of biscuits from wheat/soybean flour blends. Continental Journal of Food Science and Technology; 2: 6-13.

[16] Onwuka, G.I. (2005). Food Analysis and Instrumentation: Theory and Practice. Naphthali Publishers Ltd, Lagos, Nigeria. Pp. 38 - 44.

[17] Salvador, A. and Fiszman, S.M. (2004). Influence of the protein content on structural characteristics of stirred fermented milk. Journal of Biotechnology; 99: $237-248$. 